\title{
Comparison of Different Life Stages of Total, Phospholipid and Triacylglycerol Fatty Acids of Lucilia sericata
}

\author{
Veysi KIZMAZ
}

Artuklu University, Vocational Higher School of Healthcare Studies, Medical Laboratory Techniques, Mardin, Turkey ORCID ID: Veysi KIZMAZ: https:/ / orcid.org/0000-0002-7864-5912

Received: 05.04.2021 Accepted: 25.05.2021 Issue published: 30.06 .2021

\begin{abstract}
Lucilia sericata, which belongs to the Calliphoridae family (Diptera), is used as a debridement tool in open necrotic wounds that do not respond to conventional treatments. Knowing the total, phospholipid (PL), and triacylglycerol (TAG) fatty acid content of L. sericata fly, which is important for health, in its different stages is important both in terms of taxonomy and physiology. After L. sericata samples used in the study were obtained commercially, they were bred under laboratory conditions and then the fatty acids in different stages were analyzed by gas chromatography. Sixteen fatty acids are determined as a result of the analysis. When individual fatty acids are considered, Palmitic acid (16:0), Palmitoleic Acid (16:1n-7), oleic acid (18:1n-9) and Linoleic Acid (18:2n-6) were found to be major ones, while the others are detected in trace amounts. It is determined that, out of total, PL and TAG, saturated fatty acids (SFA) are found at a high percentage in the eggs, monounsaturated fatty acids (MUFA) are the highest in the larvae, and polyunsaturated fatty acids (PUFA) are the highest in fly and pupa. Furthermore, out of total, PL and TAG, ¿PUFA is at a low percentage in the egg and the larval stages. Different results are found at different stages in this study. This may be because fatty acid percentages that change during metamorphosis meet different physiological needs at different phases.
\end{abstract}

Keywords: Maggot, fly, Calliphoridae, gas chromatography.

\section{Lucilia sericata'nın Total, Fosfolipid ve Triaçilgliserol Yă̆ Asitlerinin Farklı Yaşam Evrelerinin Karşılaştırılması}

\begin{abstract}
Öz: Calliphoridae ailesindeki (Diptera) olan Lucilia sericata, geleneksel tedavilere yanıt veremeyen açık nekrotik yaralarda debridman aracı olarak kullanılmaktadır. Sağlık açısından önemli olan L. sericata sineğine ait farklı evrelerindeki total, fosfolipit (PL) ve triaçilgliserol (TAG) yağ asit içeriğinin bilinmesi hem taksonomik hem de fizyolojisi açllardan önem taşımaktadır. Çalışmada kullanılan L. sericata örnekleri ticari olarak temin edildikten ve laboratuvar koşullarında üremesi sağlandıktan sonra farklı evrelerindeki yağ asitleri gaz kromatografisi ile analizleri yapılmıştır. Yapılan analiz sonucunda 16 yağ asidi belirlenmiştir. Bireysel yağ asitleri incelendiğinde Palmitik asit (16:0), Palmitoleik Asit (16:1n-7), oleik asit (18:1n-9) ve Linoleik Asit (18:2n-6) majör yağ asitleri olarak belirlenmiştir. Diğerleri eser miktarda tespit edilmiştir. Total, PL ve TAG'de doymuş yağ asitleri (SFA) yumurtada; Tekli Doymamış Yağ Asitleri (MUFA) larvada, Çoklu doymamış yağ asitleri (PUFA) sinek ve pupada yüksek yüzdede olduğu belirlenmiştir. Ayrıca total, PL ve TAG'de yumurta ve larva evresinde $\sum$ PUFA'nın düşük yüzdede olduğu görülmüştür. Çalışmamızda farklı evrelerde farklı sonuçlar tespit edilmiştir. Bunun nedeni metamorfoz süresince değişen yağ asidi yüzdelerinin farklı evrelerindeki farklı fizyolojik ihtiyaçlarının karşılanması şeklinde açıklanabilir.
\end{abstract}

Anahtar kelimeler: Maggot, sinek, Calliphoridae, gaz kromotografisi.

\section{Introduction}

Lipids play a key role in insect biochemistry as energy sources, hormones, and structural compounds. It has also been found that lipids are the main energy source in insect embryogenesis (Gilbert, 1967). Dietary lipids as an energy source are more important than dietary proteins. Furthermore, fatty acids such as linoleic acid (18:2n-6) and linolenic acid (18:3n-3) play an important role in the transition from pupal to adolescent. In addition, fatty acids play an important role as precursors in the biosynthesis of waxes, pheromones, and eicosanoids. They are also known to be involved in preventive secretions (Wakayama et al., 1980; Stanley-Samuelson et al., 1988; Başhan, 1996). Eicosanoids are an important intermediate in many fields of invertebrate biology, such as reproduction (Stanley \& Miller, 1998), ion transport (Nor Aliza et al., 2001), hormone signal transfer system (Keeley et al., 1996; Ali \&
Steele, 1997) and immune system (Nor Aliza et al., 2001). Eicosanoids also occupy a place between the animal population and the host-parasite relationship in which the prey-predator relationship is involved (Nor Aliza et al., 2001). It has been reported that fatty acids stored in the form of triacylglycerol (TAG) serve as the main energy source in insects when they are not receiving food and during long flights (Downer \& Matthews, 1976; Beenakkers et al., 1985).

It has been claimed that the fatty acid composition of many insect species changes depending on the developmental stages of the insects (Stanley-Samuelson et al., 1988). Madariaga et al. (1974) found that the fatty acid distribution of Dacus oleae species, Pagani et al. (1980) gave that of Ceratitis capitata species, and Janda (1975) determined that of Galeria mellonella differs depending on the developmental stages. In their study, Hodges and 
Barras (1974) found that the fatty acid distribution in the Phospholipid (PL) fraction of the egg, the larva, the pupa, and the adult individuals of Dentroctonus frontalis was different.

In this study, Necrophage larvae of the Calliphoridae family, the most commonly Lucilia sericata, is a debridement tool used in wound treatment for biotherapy purposes in open necrotic wounds that do not respond to traditional treatments (Horobin et al., 2003; Britland et al., 2011). The average size of the adult $L$. sericata flies, which are bluish-green or metallic green, is $2-15 \mathrm{~mm}$, their eggs are small, pale yellowish-white and have cylindrical oval structure, and the larvae are headless and footless and consist of 12 segments. Peritreme are narrow and closed in posterior stigmas. Their front ends are thin, while their backsides are larger in diameter, cylindrical and there is a pair of mouth hooks or lip scleritis in the head part (Bolaban, 2009). In the present paper, it was aimed to compare the total, PL and TAG fatty acid content in different stages of $L$. sericata fly that is important for health.

\section{Material and Methods}

Commercially supplied L. sericata flies were produced in a laboratory environment at $25^{\circ} \mathrm{C}$ for 16 hours a day and 8 hours at night in $60^{*} 120 \mathrm{~cm}$ cages in the air conditioning room. Eggs were obtained by placing livers of chicken, turkey and beef in the environment where these flies lived. The eggs were collected and placed in $50 \mathrm{ml}$ test tubes and $35 \mathrm{ml}$ of $0.05 \%$ sodium hypochlorite was added to separate the eggs. At the end of this process, sodium hypochlorite was decanted, $35 \mathrm{ml}$ of $5 \%$ formaldehyde was placed on the eggs to sterilize them. The sterilized eggs were filtered in a Buchner funnel, washed with sterile isotonic 3-4 times to remove the effect of formaldehyde and the sterile eggs were transferred to a sterile liver agar medium in a $90 \mathrm{~mm}$ petri dish. After the media containing the eggs were incubated overnight at $25-30{ }^{\circ} \mathrm{C}$ in an incubator, the larvae were obtained from the eggs. Eggs obtained from adult flies, hatching larvae and pupa samples occurring from larvae were collected and stored at $-20^{\circ} \mathrm{C}$ until the samples were analyzed.

2.1. Fatty acid analysis of total, phospholipids, and triacylglycerols

Insects were homogenized in a chloroform-methanol (2:1 $\mathrm{v} / \mathrm{v}$ ) mixture in a high-speed homogenizer (Folch et al., 1957). For fractionation of TAG and PL in samples, thin layer chromatography (TLC) plates (Silica gel 60G (Merck)) were placed into the driving tank containing the mixture of petroleum ether-diethyl ether-acetic acid (80:20:1) to separate PL and TAG from each other.

\subsection{Gas Chromatography Conditions}

Fatty acid analysis of fat samples converted to methyl esters was carried out by a SHIMADZU GC 2010 PLUS model Gas Chromatography device using a flame ionization detector (FID) and DB-23 (Bonded $50 \%$ cyanopropyl) (J \& W Scientific, Folsom, CA, USA) capillary column $(30 \mathrm{~m} \times 0.25 \mathrm{~mm}$ inner diameter $\times 0.25 \mu \mathrm{m}$ film thickness). Detector temperature: $250{ }^{\circ} \mathrm{C}$; injector temperature: $250{ }^{\circ} \mathrm{C}$; injection: Split-model 1/20. Gas flow rates: Carrier gas: Helium $0.5 \mathrm{ml} / \mathrm{min}$ for $30 \mathrm{~m}$ column; hydrogen: $30 \mathrm{ml} / \mathrm{min}$; dry air: $400 \mathrm{ml} / \mathrm{min}$. Column (oven) temperature: waiting time, $2 \mathrm{~min}$ at $170{ }^{\circ} \mathrm{C} ; 2{ }^{\circ} \mathrm{C} / \mathrm{min}$ until $210^{\circ} \mathrm{C}$, waiting time $20 \mathrm{~min}$; total analysis time: 42 minutes. A mixture of methyl esters of fatty acids (Sigma-Aldrich Chemicals) was used as a standard for the identification of fatty acids. Chromatograms for methyl esters of fatty acid and amounts of total fatty acid were obtained on a computer with the computer program GC Solution (Version 2.4). Peaks in the chromatograms of the analyzed samples were identified by comparing the retention times of the methyl esters of all fatty acids in the standard. The results are given as a qualitative value in \% fatty acid. Comparison of fatty acid percentages was performed with SPSS 16 computer program by one-way analysis of variance (ANOVA). Differences were determined by the TUKEY HSD test. As a result of the statistics, the differences were considered to be significant when the data were at the $\mathrm{P}<0.05$ level.

\section{Results}

A total of 16 fatty acids were determined as a result of the analysis. The main fatty acids were determined as Palmitic Acid, Palmitoleic Acid, Stearic acid, Oleic Acid and Arachidonic Acid. Other fatty acids such as myristic and pentadecanoic were present only in trace proportions (Table 1).

The total, PL and TAG fatty acid contents (in \%) of $L$. sericata adult, pupa, larvae and eggs are given in Table. When individual fatty acids were considered, it was observed that $16: 0,16: 1 n-7,18: 1 n-9$ and $18: 2 n-6$ were major ones, while others were detected in trace amounts. Out of total, PL and TAG, percentage of 16:0 was the highest in the egg, while it was the lowest in pupa out of total and TAG; the percentage of $16: 1 n-7$ was similar in all phases; 18:1n-9 was the highest in the larva out of total and PL, in the pupa out of TAG, while it was the lowest in the egg out of total, in the pupa out of PL, and in the fly out of TAG. On the other hand, the percentage of $18: 2 n-6$ was the lowest in the egg and larva, while it was at a similar percentage in the other stages (Table 1).

Total fatty acid distribution was in the order of MUFA $>$ SFA $>$ PUFA in all except eggs, while this order was SFA $>$ MUFA $>$ PUFA in the egg. Out of PL, there was an order of MUFA $>$ PUFA $>S F A$ in the fly, SFA $>$ MUFA $>$ PUFA in the egg, MUFA $>$ SFA $>$ PUFA in the larva, and SFA=MUFA $>$ PUFA in the pupa. Out of TAG, the order was SFA $>$ MUFA $>$ PUFA in the fly and in the egg, MUFA $>$ SFA $>$ PUFA in the larva, MUFA $>$ SFA $=$ PUFA in the pupa. Out of total, PL and TAG, the percentage of $\sum$ SFA was the highest in the egg. In total MUFA, total and PL were the highest in the larva, TAG was the highest in the pupa, while PUFA was at the lowest percentage in the egg and larva (Table 1).

When the total fatty acid distribution was considered, it was found that 16:0 and consequently total SFA increased, while 18:1n-9, EMUFA, 18:2n-6 and $\sum$ PUFA decreased in the egg. In the case of the larva, 18:1n9 and $\sum$ MUFA increased, whereas 18:2n-6 and $\sum$ PUFA decreased. Out of PL, the percentage of 16:0 and consequently total SFA was high in the egg, while that of 18:2 and total PUFA was low. In the case of the larva, the percentage of 18:1n-9 and total MUFA increased, whereas that of 18:2n-6 and total PUFA decreased. Out of TAG, the percentage of 16:0 and consequently total SFA was high in the egg, while that of $18: 2 n-6$ and total PUFA was low. 
Percentage of 18:1n-9 and total MUFA increased, while that of 18:2n-6 and total PUFA decreased in the larva. Out of total, PL and TAG fatty acid, percentage of SFA was high in the egg, percentage of MUFA was high in the larva, whereas that of PUFA was high in the fly and pupa. Furthermore, out of total, PL and TAG, the percentage of $\sum$ PUFA was low in the egg and larval stages (Table).

Table 1. Distribution of fatty acid Total. Phospholipids (PL), and Triaçilgliserol (TAG) in Lucilia sericata

\begin{tabular}{|c|c|c|c|c|c|c|c|c|c|c|c|c|}
\hline & Total & & & & PL & & & & TAG & & & \\
\hline Fatty Acid & Adults & Eggs & Larvae & Pupae & Adults & Eggs & Larvae & Pupae & Adults & Eggs & Larvae & Pupae \\
\hline $12: 0$ & $\begin{array}{c}0.08 \\
\pm 0.01\end{array}$ & $\begin{array}{c}0.24 \\
\pm 0.02\end{array}$ & $\begin{array}{c}0.59 \\
\pm 0.05\end{array}$ & $\begin{array}{c}0.09 \\
\pm 0.01\end{array}$ & $\begin{array}{c}0.18 \\
\pm 0.01\end{array}$ & $\begin{array}{c}0.17 \\
\pm 0.01\end{array}$ & $\begin{array}{c}0.08 \\
\pm 0.01\end{array}$ & $\begin{array}{c}0.10 \\
\pm 0.01\end{array}$ & $\begin{array}{c}0.11 \\
\pm 0.01\end{array}$ & $\begin{array}{c}0.18 \\
\pm 0.01\end{array}$ & $\begin{array}{c}0.25 \\
\pm 0.02\end{array}$ & $\begin{array}{c}0.16 \\
\pm 0.01\end{array}$ \\
\hline $14: 0$ & $\begin{array}{c}2.02 \\
\pm 0.16\end{array}$ & $\begin{array}{c}3.62 \\
\pm 0.29\end{array}$ & $\begin{array}{c}3.07 \\
\pm 0.24\end{array}$ & $\begin{array}{c}1.90 \\
\pm 0.15\end{array}$ & $\begin{array}{c}0.98 \\
\pm 0.08\end{array}$ & $\begin{array}{c}2.92 \\
\pm 0.23\end{array}$ & $\begin{array}{c}2.28 \\
\pm 0.18\end{array}$ & $\begin{array}{c}1.69 \\
\pm 0.13\end{array}$ & $\begin{array}{c}2.91 \\
\pm 0.23\end{array}$ & $\begin{array}{c}3.53 \\
\pm 0.28\end{array}$ & $\begin{array}{c}3.19 \\
\pm 0.25\end{array}$ & $\begin{array}{c}1.04 \\
\pm 0.08\end{array}$ \\
\hline $15: 0$ & $\begin{array}{c}0.29 \\
\pm 0.02\end{array}$ & $\begin{array}{c}0.68 \\
\pm 0.05\end{array}$ & $\begin{array}{c}0.40 \\
\pm 0.03\end{array}$ & $\begin{array}{c}0.19 \\
\pm 0.02\end{array}$ & $\begin{array}{c}0.20 \\
\pm 0.02\end{array}$ & $\begin{array}{c}0.39 \\
\pm 0.03\end{array}$ & $\begin{array}{c}0.49 \\
\pm 0.04\end{array}$ & $\begin{array}{c}0.41 \\
\pm 0.03\end{array}$ & $\begin{array}{c}0.16 \\
\pm 0.01\end{array}$ & $\begin{array}{c}0.70 \\
\pm 0.06\end{array}$ & $\begin{array}{c}0.39 \\
\pm 0.03\end{array}$ & $\begin{array}{c}0.09 \\
\pm 0.01\end{array}$ \\
\hline $16: 0$ & $\begin{array}{l}24.56 \\
\pm 1.96\end{array}$ & $\begin{array}{l}42.18 \\
\pm 3.37\end{array}$ & $\begin{array}{l}26.22 \\
\pm 2.09\end{array}$ & $\begin{array}{l}22.81 \\
\pm 1.82\end{array}$ & $\begin{array}{l}20.47 \\
\pm 1.63\end{array}$ & $\begin{array}{l}36.07 \\
\pm 2.88\end{array}$ & $\begin{array}{l}27.00 \\
\pm 2.15\end{array}$ & $\begin{array}{l}31.96 \\
\pm 2.55\end{array}$ & $\begin{array}{l}30.73 \\
\pm 2.45\end{array}$ & $\begin{array}{l}35.27 \\
\pm 2.81\end{array}$ & $\begin{array}{l}27.73 \\
\pm 2.21\end{array}$ & $\begin{array}{l}12.81 \\
\pm 1.02\end{array}$ \\
\hline $17: 0$ & $\begin{array}{c}0.17 \\
\pm 0.01\end{array}$ & $\begin{array}{c}0.06 \\
\pm 0.01\end{array}$ & $\begin{array}{c}0.27 \\
\pm 0.02\end{array}$ & $\begin{array}{c}0.14 \\
\pm 0.01\end{array}$ & $\begin{array}{c}0.33 \\
\pm 0.03\end{array}$ & $\begin{array}{c}0.28 \\
\pm 0.02\end{array}$ & $\begin{array}{c}0.30 \\
\pm 0.02\end{array}$ & $\begin{array}{c}0.14 \\
\pm 0.01\end{array}$ & $\begin{array}{c}0.20 \\
\pm 0.02\end{array}$ & $\begin{array}{c}0.26 \\
\pm 0.02\end{array}$ & $\begin{array}{c}0.26 \\
\pm 0.02\end{array}$ & $\begin{array}{c}0.08 \\
\pm 0.01\end{array}$ \\
\hline 18:0 & $\begin{array}{c}5.52 \\
\pm 0.44\end{array}$ & $\begin{array}{c}8.26 \\
\pm 0.66\end{array}$ & $\begin{array}{c}2.08 \\
\pm 0.17\end{array}$ & $\begin{array}{c}5.56 \\
\pm 0.44\end{array}$ & $\begin{array}{c}4.87 \\
\pm 0.39\end{array}$ & $\begin{array}{l}12.09 \\
\pm 0.96\end{array}$ & $\begin{array}{c}1.20 \\
\pm 0.10\end{array}$ & $\begin{array}{c}3.00 \\
\pm 0.24\end{array}$ & $\begin{array}{c}8.19 \\
\pm 0.65\end{array}$ & $\begin{array}{c}7.44 \\
\pm 0.59\end{array}$ & $\begin{array}{c}2.39 \\
\pm 0.19\end{array}$ & $\begin{array}{c}3.88 \\
\pm 0.31\end{array}$ \\
\hline$\sum$ S.F.A. & $\begin{array}{l}32.64 \\
\pm 2.60\end{array}$ & $\begin{array}{l}55.05 \\
\pm 4.39\end{array}$ & $\begin{array}{l}32.63 \\
\pm 2.60\end{array}$ & $\begin{array}{r}30.69 \\
\pm 2.45\end{array}$ & $\begin{array}{l}27.03 \\
\pm 2.16\end{array}$ & $\begin{array}{l}51.92 \\
\pm 4.14\end{array}$ & $\begin{array}{l}31.35 \\
\pm 2.50\end{array}$ & $\begin{array}{l}37.29 \\
\pm 2.98\end{array}$ & $\begin{array}{l}42.29 \\
\pm 3.37\end{array}$ & $\begin{array}{l}47.37 \\
\pm 3.78\end{array}$ & $\begin{array}{l}34.21 \\
\pm 2.73\end{array}$ & $\begin{array}{l}18.07 \\
\pm 1.44\end{array}$ \\
\hline $16: 1 n-7$ & $\begin{array}{l}14.19 \\
\pm 1.13\end{array}$ & $\begin{array}{l}13.51 \\
\pm 1.08\end{array}$ & $\begin{array}{l}13.37 \\
\pm 1.07\end{array}$ & $\begin{array}{l}13.50 \\
\pm 1.08\end{array}$ & $\begin{array}{l}14.13 \\
\pm 1.13\end{array}$ & $\begin{array}{c}5.82 \\
\pm 0.46\end{array}$ & $\begin{array}{l}19.06 \\
\pm 1.52\end{array}$ & $\begin{array}{l}12.37 \\
\pm 0.99\end{array}$ & $\begin{array}{l}12.27 \\
\pm 0.98\end{array}$ & $\begin{array}{l}11.83 \\
\pm 0.94\end{array}$ & $\begin{array}{l}11.89 \\
\pm 0.95\end{array}$ & $\begin{array}{c}5.05 \\
\pm 0.40\end{array}$ \\
\hline $18: 1 n-9$ & $\begin{array}{l}25.64 \\
\pm 2.05\end{array}$ & $\begin{array}{l}16.82 \\
\pm 1.34\end{array}$ & $\begin{array}{l}41.00 \\
\pm 3.27\end{array}$ & $\begin{array}{l}26.73 \\
\pm 2.13\end{array}$ & $\begin{array}{l}26.41 \\
\pm 2.11\end{array}$ & $\begin{array}{l}31.14 \\
\pm 2.48\end{array}$ & $\begin{array}{l}35.45 \\
\pm 2.83\end{array}$ & $\begin{array}{r}22.75 \\
\pm 1.82\end{array}$ & $\begin{array}{l}27.60 \\
\pm 2.20\end{array}$ & $\begin{array}{l}29.11 \\
\pm 2.32\end{array}$ & $\begin{array}{l}43.34 \\
\pm 3.46\end{array}$ & $\begin{array}{l}58.40 \\
\pm 4.66\end{array}$ \\
\hline $20: 1 n-9$ & $\begin{array}{c}0.33 \\
\pm 0.03\end{array}$ & $\begin{array}{c}0.54 \\
\pm 0.04\end{array}$ & $\begin{array}{c}0.30 \\
\pm 0.02\end{array}$ & $\begin{array}{c}0.15 \\
\pm 0.01\end{array}$ & $\begin{array}{c}0.84 \\
\pm 0.07\end{array}$ & $\begin{array}{c}0.77 \\
\pm 0.06\end{array}$ & $\begin{array}{c}0.31 \\
\pm 0.02\end{array}$ & $\begin{array}{c}0.47 \\
\pm 0.04\end{array}$ & $\begin{array}{c}0.41 \\
\pm 0.03\end{array}$ & $\begin{array}{c}0.38 \\
\pm 0.03\end{array}$ & $\begin{array}{c}0.35 \\
\pm 0.03\end{array}$ & $\begin{array}{c}0.49 \\
\pm 0.04\end{array}$ \\
\hline$\sum$ M.U.F.A. & $\begin{array}{l}40.16 \\
\pm 3.20\end{array}$ & $\begin{array}{l}30.87 \\
\pm 2.46\end{array}$ & $\begin{array}{l}54.67 \\
\pm 4.36\end{array}$ & $\begin{array}{l}40.39 \\
\pm 3.22\end{array}$ & $\begin{array}{l}41.37 \\
\pm 3.30\end{array}$ & $\begin{array}{l}37.74 \\
\pm 3.01\end{array}$ & $\begin{array}{l}54.81 \\
\pm 4.37\end{array}$ & $\begin{array}{l}35.59 \\
\pm 2.84\end{array}$ & $\begin{array}{l}40.28 \\
\pm 3.21\end{array}$ & $\begin{array}{l}41.32 \\
\pm 3.30\end{array}$ & $\begin{array}{l}55.58 \\
\pm 4.43\end{array}$ & $\begin{array}{r}63.94 \\
\pm 5.10\end{array}$ \\
\hline $18: 2 n-6$ & $\begin{array}{l}20.54 \\
\pm 1.64\end{array}$ & $\begin{array}{l}10.74 \\
\pm 0.86\end{array}$ & $\begin{array}{c}9.86 \\
\pm 0.79\end{array}$ & $\begin{array}{l}21.44 \\
\pm 1.71\end{array}$ & $\begin{array}{l}23.23 \\
\pm 1.85\end{array}$ & $\begin{array}{c}6.69 \\
\pm 0.53\end{array}$ & $\begin{array}{l}11.70 \\
\pm 0.93\end{array}$ & $\begin{array}{l}19.96 \\
\pm 1.59\end{array}$ & $\begin{array}{l}13.71 \\
\pm 1.09\end{array}$ & $\begin{array}{c}8.80 \\
\pm 0.70\end{array}$ & $\begin{array}{c}8.23 \\
\pm 0.66\end{array}$ & $\begin{array}{l}14.57 \\
\pm 1.16\end{array}$ \\
\hline $18: 3 n-6$ & $\begin{array}{c}0.49 \\
\pm 0.04\end{array}$ & $\begin{array}{c}0.59 \\
\pm 0.05\end{array}$ & $\begin{array}{c}0.14 \\
\pm 0.01\end{array}$ & $\begin{array}{c}0.71 \\
\pm 0.06\end{array}$ & $\begin{array}{c}0.46 \\
\pm 0.04\end{array}$ & $\begin{array}{c}0.35 \\
\pm 0.03\end{array}$ & $\begin{array}{c}0.15 \\
\pm 0.01\end{array}$ & $\begin{array}{c}0.49 \\
\pm 0.04\end{array}$ & $\begin{array}{c}0.40 \\
\pm 0.03\end{array}$ & $\begin{array}{c}0.36 \\
\pm 0.03\end{array}$ & $\begin{array}{c}0.09 \\
\pm 0.01\end{array}$ & $\begin{array}{c}0.22 \\
\pm 0.02\end{array}$ \\
\hline $18: 3 n-3$ & $\begin{array}{c}0.49 \\
\pm 0.04\end{array}$ & $\begin{array}{c}0.21 \\
\pm 0.02\end{array}$ & $\begin{array}{c}0.32 \\
\pm 0.03\end{array}$ & $\begin{array}{c}0.44 \\
\pm 0.03\end{array}$ & $\begin{array}{c}0.88 \\
\pm 0.07\end{array}$ & $\begin{array}{c}0.30 \\
\pm 0.02\end{array}$ & $\begin{array}{c}0.22 \\
\pm 0.02\end{array}$ & $\begin{array}{c}0.36 \\
\pm 0.03\end{array}$ & $\begin{array}{c}0.29 \\
\pm 0.02\end{array}$ & $\begin{array}{c}0.45 \\
\pm 0.04\end{array}$ & $\begin{array}{c}0.17 \\
\pm 0.01\end{array}$ & $\begin{array}{c}1.29 \\
\pm 0.10\end{array}$ \\
\hline $20: 2 n-6$ & $\begin{array}{c}0.06 \\
\pm 0.00\end{array}$ & $\begin{array}{c}0.03 \\
\pm 0.00\end{array}$ & $\begin{array}{c}0.18 \\
\pm 0.01\end{array}$ & $\begin{array}{c}0.16 \\
\pm 0.01\end{array}$ & $\begin{array}{c}0.08 \\
\pm 0.01\end{array}$ & $\begin{array}{c}0.35 \\
\pm 0.03\end{array}$ & $\begin{array}{c}0.06 \\
\pm 0.00\end{array}$ & $\begin{array}{c}0.07 \\
\pm 0.01\end{array}$ & $\begin{array}{c}0.08 \\
\pm 0.01\end{array}$ & $\begin{array}{c}0.15 \\
\pm 0.01\end{array}$ & $\begin{array}{c}0.23 \\
\pm 0.02\end{array}$ & $\begin{array}{c}0.08 \\
\pm 0.01\end{array}$ \\
\hline $20: 3 n-6$ & $\begin{array}{c}0.11 \\
\pm 0.01\end{array}$ & $\begin{array}{c}0.08 \\
\pm 0.01\end{array}$ & $\begin{array}{c}0.31 \\
\pm 0.02\end{array}$ & $\begin{array}{c}0.20 \\
\pm 0.02\end{array}$ & $\begin{array}{c}0.07 \\
\pm 0.01\end{array}$ & $\begin{array}{c}0.11 \\
\pm 0.01\end{array}$ & $\begin{array}{c}0.22 \\
\pm 0.02\end{array}$ & $\begin{array}{c}0.10 \\
\pm 0.01\end{array}$ & $\begin{array}{c}0.13 \\
\pm 0.01\end{array}$ & $\begin{array}{c}0.09 \\
\pm 0.01\end{array}$ & $\begin{array}{c}0.29 \\
\pm 0.02\end{array}$ & $\begin{array}{c}0.05 \\
\pm 0.00\end{array}$ \\
\hline $20: 4 n-6$ & $\begin{array}{c}4.39 \\
\pm 0.35\end{array}$ & $\begin{array}{c}2.07 \\
\pm 0.17\end{array}$ & $\begin{array}{c}1.52 \\
\pm 0.12\end{array}$ & $\begin{array}{c}5.43 \\
\pm 0.43\end{array}$ & $\begin{array}{c}4.27 \\
\pm 0.34\end{array}$ & $\begin{array}{c}1.53 \\
\pm 0.12\end{array}$ & $\begin{array}{c}1.35 \\
\pm 0.11\end{array}$ & $\begin{array}{c}5.13 \\
\pm 0.41\end{array}$ & $\begin{array}{c}2.34 \\
\pm 0.19\end{array}$ & $\begin{array}{c}1.03 \\
\pm 0.08\end{array}$ & $\begin{array}{c}1.11 \\
\pm 0.09\end{array}$ & $\begin{array}{c}1.45 \\
\pm 0.12\end{array}$ \\
\hline $20: 5 n-3$ & $\begin{array}{c}1.12 \\
\pm 0.09\end{array}$ & $\begin{array}{c}0.36 \\
\pm 0.03\end{array}$ & $\begin{array}{c}0.38 \\
\pm 0.03\end{array}$ & $\begin{array}{c}0.54 \\
\pm 0.04\end{array}$ & $\begin{array}{c}2.61 \\
\pm 0.21\end{array}$ & $\begin{array}{c}1.01 \\
\pm 0.08\end{array}$ & $\begin{array}{c}0.15 \\
\pm 0.01\end{array}$ & $\begin{array}{c}1.01 \\
\pm 0.08\end{array}$ & $\begin{array}{c}0.48 \\
\pm 0.04\end{array}$ & $\begin{array}{c}0.43 \\
\pm 0.03\end{array}$ & $\begin{array}{c}0.10 \\
\pm 0.01\end{array}$ & $\begin{array}{c}0.33 \\
\pm 0.03\end{array}$ \\
\hline$\sum$ P.U.F.A. & $\begin{array}{l}27.20 \\
\pm 2.17\end{array}$ & $\begin{array}{l}14.08 \\
\pm 1.12\end{array}$ & $\begin{array}{l}12.70 \\
\pm 1.01\end{array}$ & $\begin{array}{l}28.92 \\
\pm 2.31\end{array}$ & $\begin{array}{l}31.60 \\
\pm 2.52\end{array}$ & $\begin{array}{l}10.35 \\
\pm 0.83\end{array}$ & $\begin{array}{l}13.84 \\
\pm 1.10\end{array}$ & $\begin{array}{l}27.12 \\
\pm 2.16\end{array}$ & $\begin{array}{l}17.43 \\
\pm 1.39\end{array}$ & $\begin{array}{l}11.31 \\
\pm 0.90\end{array}$ & $\begin{array}{l}10.21 \\
\pm 0.81\end{array}$ & $\begin{array}{r}17.99 \\
\pm 1.44\end{array}$ \\
\hline n3 & $\begin{array}{c}1.61 \\
\pm 0.13\end{array}$ & $\begin{array}{c}0.57 \\
\pm 0.05\end{array}$ & $\begin{array}{c}0.69 \\
\pm 0.06\end{array}$ & $\begin{array}{c}0.98 \\
\pm 0.08\end{array}$ & $\begin{array}{c}3.49 \\
\pm 0.28\end{array}$ & $\begin{array}{c}1.32 \\
\pm 0.10\end{array}$ & $\begin{array}{c}0.37 \\
\pm 0.03\end{array}$ & $\begin{array}{c}1.37 \\
\pm 0.11\end{array}$ & $\begin{array}{c}0.77 \\
\pm 0.06\end{array}$ & $\begin{array}{c}0.88 \\
\pm 0.07\end{array}$ & $\begin{array}{c}0.27 \\
\pm 0.02\end{array}$ & $\begin{array}{c}1.62 \\
\pm 0.13\end{array}$ \\
\hline n6 & $\begin{array}{r}25.59 \\
\pm 2.04\end{array}$ & $\begin{array}{l}13.51 \\
\pm 1.08\end{array}$ & $\begin{array}{l}12.00 \\
\pm 0.96\end{array}$ & $\begin{array}{l}27.94 \\
\pm 2.23\end{array}$ & $\begin{array}{l}28.11 \\
\pm 2.24\end{array}$ & $\begin{array}{c}9.03 \\
\pm 0.72\end{array}$ & $\begin{array}{l}13.47 \\
\pm 1.07\end{array}$ & $\begin{array}{l}25.75 \\
\pm 2.05\end{array}$ & $\begin{array}{l}16.66 \\
\pm 1.33\end{array}$ & $\begin{array}{l}10.43 \\
\pm 0.83\end{array}$ & $\begin{array}{c}9.94 \\
\pm 0.79\end{array}$ & $\begin{array}{l}16.37 \\
\pm 1.31\end{array}$ \\
\hline $\mathrm{n} 3 / \mathrm{n} 6$ & 0.06 & 0.04 & 0.06 & 0.04 & 0.12 & 0.15 & 0.03 & 0.05 & 0.05 & 0.08 & 0.03 & 0.10 \\
\hline
\end{tabular}

Values are provided as mean $\pm \mathrm{SE}$

SFA saturated fatty acid, MUFA monounsaturated fatty acid, PUFA polyunsaturated fatty acid

\section{Discussion}

A total of 13 fatty acids, 3 monounsaturated and 8 polyunsaturated, were detected in the analysis performed on the larva and the adults of Ochlerotatus euedus, O. subdiversus, O. flavescens, O. caspius, Aedes cinereus and Anopheles messeae (Sushchik et al., 2013). In their work Gołębiowski et al. (2014) identified a total of 26 fatty acids, 6 monounsaturated and 3 polyunsaturated, between C6 and C24 in L. sericata larva, and a total of 21 fatty acids in pupa, 4 monounsaturated and 3 polyunsaturated. It was found that $16: 0(20.5 \%), 16: 1 n-9(15.4 \%)$, and $18: 1 n-9$ $(56.9 \%)$ as the major fatty acid in the larva; $16: 0(29.5 \%)$, $16: 1 n-9(16.0 \%)$, and $18: 1 n-9(45.6 \%)$ as the major fatty acid in the pupa. Zhang et al. (2010) determined a total of 10 fatty acids in their total fatty acid analysis on L. sericata larvae. They determined SFA as $20.57 \%$, MUFA $60.32 \%$ and PUFA $19.11 \%$. In our study, out of total fatty acid, the highest one was MUFA (54.67\%), then SFA (32.63\%) and the lowest one was PUFA (12.70\%), showing a similar distribution with that study. However, unlike that study, 16 fatty acids were found in our study.

Palmitic and oleic acids were at the highest level in the samples of all species in the analysis carried out on the egg samples of four fly species. Percentage of palmitic acid was $30.40 \%$ in L. excision, $30.68 \%$ in C. megacephaly, $31.08 \%$ in L. cuprina, $30.29 \%$ in C. albiceps, whereas that of oleic acid was found to be $41.03 \%$ in L. excision, $40.81 \%$ in C. megacephaly, $44.9 \%$ in L. cuprina, and $41.03 \%$ in C. albiceps. 
L. cuprin had the highest oleic acid concentration. It has been noted that the fatty acid composition of different samples varies quantitatively between genera and even species (Lunas et al., 2019). In our study, it was similarly high in terms of total fatty acid. However, the percentage of palmitic acid was the highest in the egg $(42.18 \%)$, while that of oleic acid was higher in the larva $(41.00 \%)$. Hence, the values in different life stages of the same sample were different. These results are similar to the findings of Jacob and Hanssen (1979) who described the quantitative differences between fatty acid profiles of four adult dragonfly species. Likewise, Thompson (1973) and Paul et al. (2017) stated that the fatty acid compositions of different insect species showed significant quantitative differences. These data in our study are very important for determining the quantitative differences in taxonomic terms.

Gołębiowski et al. (2012) found that female and male L. sericata fatty acid profiles were from $\mathrm{C} 6$ to $\mathrm{C} 20$, a total of 15 fatty acids in males and 16 in females. They found that $16: 0$ (29.4\% in females, $19.5 \%$ in males), $16: 1 n-9$ (10.3\% in females, $14.7 \%$ in males) and $18: 1 n-9$ (40.6\% in females and $57.4 \%$ in males) were major fatty acids in both sexes. In our study, 16:0 (25.56\%), 16:1n-9 (14.19\%), 18:1n-9 (25.64\%) and $18: 2 \mathrm{n}-6(20.54 \%)$ were determined to be major ones. Monounsaturated and polyunsaturated fatty acids are generally found in many insect species. Although these fatty acids are detected in aquatic insect larvae Stictochironomus pictulus lipids, the presence of polyunsaturated fatty acids at 20:4n-3 and 20:5n-3 is rather unusual. In their study, they found that the ratio of 20:4n3 and $20: 5 n-3$ were 1.6 and $1.0 \%$ in females. In our study, the percentage of $20: 4 n-3$ was between $1.03 \%$ and $5.43 \%$, while that of $20: 5 n-3$ was between $0.33 \%$ and $2.61 \%$ out of total, PL and TAG.

Cakmak et al. (2004) studied different developmental stages and different lipid fractions of Myrmeleon inconspicuus species. In this study, they observed that there was a decrease in $16: 1 n-7$, while an increase was observed in 18:2n-6 in the adult stage in both fatty acid distributions in the PL and TAG fractions of M. inconspicuus larva and adult individuals. In our study, 16:1n-7 PL was low in the egg $(5.82 \%)$, TAG was low in the pupa $(5.05 \%)$, and the percentage of PL was highest in Larva (19.06\%), whereas it was similar in pupa $(12.37 \%)$ and fly $(14.13 \%)$. TAG showed a similar distribution in the fly $(12.27 \%)$, the egg (11.83\%) and the larva (11.89\%). In the case of 18:2n-6, PL was three times lower in egg and two times lower in larva than that in fly and pupa. TAG decreased $56 \%$ in eggs and larvae compared to flies and pupae. Ogg and StanleySamuelson (1992) suggested that insects undergoing different metamorphoses have different fatty acid content. In their study, they determined that the differences observed in the fatty acid distribution in the egg, larva, pupa, and adult stages of insects undergoing holometabol metamorphosis were more pronounced than those observed in insects with hemimetabol. This is because the extent of tissue organization in insects undergoing complete metamorphosis (holometabol) is more complex than insects that undergo semi-metamorphosis (hemimetabol) (Crippsc \& De Renobales, 1988).

As a result of the investigation of the fatty acid composition of the late stage larva and pupa of Achroia grisella; there was no statistical difference between the two groups in terms of SFA percentages, while the percentage of unsaturated fatty acids was higher in the larval stage than that in the pupal stage, and the percentage of supersaturated fatty acids was higher in the pupal stage compared to that in the larval stage. The reason for these differences was explained as the different physiological needs that occur during the metamorphosis of insects (Nurullahoglu, 2003). In our study, out of SFA, total, and PL was statistically high in the eggs; out of TAG, they were low in the larva and the pupa. In the case of MUFA, total, PL and TAG were 1.7 times higher in the larva than fly, egg and pupae. The percentage of supersaturated fatty acids was approximately two times lower in the eggs and larvae compared to other stages.

In a study conducted on G. mellonella, the percentages of 18:1n-9 and 16:0 were very high, while the percentage of $18: 2 n-6$ was the third largest one in the fatty acid profile of the fifth, sixth and seventh stage larvae and pupae of the species (Aktümsek et al., 2000). Similar results were found in our study. The percentage of 16:0 and 18:1n-9 increased significantly, while the percentage of $18: 2 n-6$ decreased from the 5th larval stage to the pupal stage of G. mellonella, and the percentage of 18:3n-3 was lower in the 6 th and 7 th stage larva than that in the 5 th stage, whereas it was higher in the pupal stage. This is because varying fatty acid percentages during metamorphosis meet different physiological needs in different stages of the insect (Aktümsek et al., 2000). In our research, it was found that 16:0 is higher out of total, PL, and TAG in the larva and 18:1n-9 is higher in pupa out of TAG; $18: 2 n-6$ and 18:3n-3 were found to be similarly lower. This is due to the difference between species during metamorphosis. In another study, the percentage of 16:1n-7, 16:0, and 18:1n-9 was high and similar in the fatty acid composition of $A$. grisella larva and pupa (Nurullahoglu, 2003). Another study showed that the highest percentages in the fatty acid composition of end stage larva and pupa of $P$. interpunctella correspond to 18:1n-9 and 16:0 (Seven, 2004). In the analysis of fatty acid composition of the late stage larva and pupa of Tenebrio molitor, Taskin and Aksoylar (2010) found that 12:0-18:2n-6 fatty acids are responsible for the total fatty acid composition in both stages. They found that oleic acid had the highest percentage and 16:0 and 18:2n-6's also had high percentages. In our research data, we found that 16:0, 18:1n-9 and 18:2n-6 were high out of total, PL, and TAG. Oleic acid is a fatty acid used for growth and as an energy source (Dadd, 1973). They attributed the reason for the high oleic acid in insects to this, which was found to be similarly high in our study as well.

Kalyoncu and Ozge (2014) investigated the fatty acid composition of $P$. interpunctella larvae, pupae, and adults. They identified 20 fatty acids ranging from 12-22 carbon fatty acids as a result of the analysis and determined that the largest percentage in the larval developmental stage corresponded to 16:0 while 18:1n-9 had the highest percentage in the pupal and adult stages. According to our research data, out of total fatty acids, 16:0 had the highest percentage out of saturated fatty acids; $18: 1 n-9$ was high in the other stages except egg $(16.82 \%)$, out of the monounsaturated fatty acids. This fatty acid was found to be 1.58 times more in the larva. They found that the percentage of SFA was the highest in the larval stage, 
while the percentage of PUFA was the highest in the pupal stage, and they stated that there were differences in fatty acid percentages depending on the developmental stages (Kalyoncu \& Ozge, 2014).

Insects meet their energy needs from stored TAGs during their pupal stages. During the pupa phase, TAG is consumed slowly, accelerating towards the end of the metamorphosis (Ogg \& Stanley-Samuelson, 1992). In their study on the fatty acid composition in PL and TAG fractions of $M$. inconspicuus larva and adult individuals, Cakmak et al. (2004) found that 16:1n-7 decreased, whereas 18:2n-6 increased in both fractions in the adult stage. In our study, similar decreases and increases were observed in both PL and TAG.

$18: 2 n-6,20: 3 n-6$ and $20: 4 n-6$ in the PL fraction of thorax of individuals belonging to the $P$. americana species, and 18:1n-9 and eicosadienoic acid (20:2n-6) in the abdomen part were higher than those in other body parts (Jurenka et al., 1988). The ratio of 18:2n-6 was high in the PL fraction of the head and thorax of female and male individuals of the Magicicada septendecim, and that of 18:1n9 was high in the abdomen (Hoback et al., 1999). In our investigation, 16:1n-7, 18:1n-9 and 20:3n-6 were higher in the larva; 18:2n-6, 20:4n-6 and 20:5n-3 in the pupa, 20:2n-6 and 20:5n-3 in the eggs. Phospholipid fatty acid content was different in eggs, larvae, pupae, and adults of $D$. frontalis (Hodges \& Barras, 1974). Ogg and StanleySamuelson (1992) obtained similar findings from M. sexta. Bozkus (2003) noted increases and decreases in fatty acids in PL fractions at different developmental stages such as nymphs and adults. Similarly, in our study, it was observed that different fatty acids were present at different stages.

Ethics committee approval: Ethics committee approval is not required for this study.

Conflict of interest: The authors declares that there is no conflict of interest.

\section{References}

Aktümsek, A., Nurullahoglu, Z.Ü., \& Kalyoncu, L. (2000). Fatty Acid Composition of Galleria mellonella (L.) (Lepidoptera : Pyralidae) Larvae and Pupae Selcuk University Journal of Science, 17, 29-32.

Ali, I., \& Steele, J.E. (1997). Evidence that free fatty acids in trophocytes of Periplaneta americana fat body may be regulated by the activity of phospholipase A2 and cyclooxygenase. Insect Biochem Molecular and Biology, 27(7), 681-692. https:/ / doi.org/10.1016/s0965-1748(97)00046-5

Başhan, M. (1996). Effect of various diets on the total lipid compositions the black cricket Melanogrillus desertus Pall. Turkish Journal of Zoology, 20, 376-379.

Beenakkers, A., M.Th. Van der Horst, D.J., \& Van Marrewijk, W.J.A. (1985). Insect lipids and lipoproteins, and their role in physiological processes. Progress in Lipid Research, 24(1), 19-67. https://doi.org/10.1016/01637827(85)90007-4

Bolaban, D. (2009). Lucilia sericata Larvalari ve Salgilarinin Metisiline Dirençli Staphylococcus Aureus (Mrsa) ve Metisiline Duyarli Staphylococcus Aureus (Mssa) Üzerine Antibakteriyel Etkilerinin İn-Vivo ve İn-Vitro Koşullarda Araştırılması. (236201), Retrieved https://tez.yok.gov.tr/UlusalTezMerkezi/tezSorguSonucYeni.jsp

Bozkus, K. (2003). Phospholipid and Triacylglycerol Fatty Acid Compositions from Various Development Stages of Melanogryllus Desertus Pall. (Orthoptera: Gryllidae). Turkish Journal of Biology, (27), 7378.

Britland, S., Smith, A., Finter, W., Eagland, D., Vowden, K., Vowden, P., Pritchard, D. (2011). Recombinant Lucilia sericata chymotrypsin in a topical hydrogel formulation degrades human wound eschar ex vivo. Biotechnology Progress, 27(3), 870-874. https://doi.org/10.1002/btpr.587
Cakmak, Ö., Bashan, M., \& Satar, A. (2004). Fatty acid content of larvae and adult individuals of Myrmeleon inconspicuus (Neuroptera, Myrmeleonidae). Paper presented at the XVII. National Biology Congress, Adana, Turkey.

Crippsc, C., \& De Renobales, M. (1988). Developmental changes in fatty acid biosynthesis and composition in the house cricket, Acheta domesticus. Archives of Insect Biochemistry and Physiology, 9(4), 357-366. https://doi.org/10.1002/arch.940090409

Dadd, R.H. (1973). Insect nutrition: current developments and metabolic implications. Annual Review of Entomology, 18, 381-420. https:/ / doi.org/10.1146/annurev.en.18.010173.002121

Downer, R.G.H., \& Matthews, J.R. (1976). Patterns of Lipid Distribution and Utilisation in Insects. American Zoologist, 16(4), 733-745. https://doi.org/10.1093/icb/16.4.733

Folch, J., Lees, M., \& Sloane Stanley, G.H. (1957). A simple method for the isolation and purification of total lipids from animal tissues. The Journal of Biological Chemistry, 226(1), 497-509.

Gilbert, L.I. (1967). Lipid Metabolism and Function in Insects. In J.W.L. Beament, J.E. Treherne, \& V.B. Wigglesworth (Eds.), Advances in Insect Physiology (Vol. 4, pp. 69-211): Academic Press.

Gołębiowski, M., Boguś, M.I., Paszkiewicz, M., Wieloch, W., Włóka, E., \& Stepnowski, P. (2012). The Composition of the Cuticular and Internal Free Fatty Acids and Alcohols from Lucilia sericata Males and Females. Lipids, 47(6), 613-622. https:/ / doi.org/10.1007/s11745-012-3662-5

Gołębiowski, M., Sosnowska, A., Puzyn, T., Boguś, M.I., Wieloch, W., Włóka, E., \& Stepnowski, P. (2014). Application of two-way hierarchical cluster analysis for the identification of similarities between the individual lipid fractions of Lucilia sericata. Chemistry and Biodiversity, 11(5), 733-748. https:// doi.org/10.1002/cbdv.201300294

Hoback, W.W., Rana, R.L., \& Stanley, D.W. (1999). Fatty acid compositions of phospholipids and triacylglycerols of selected tissues, and fatty acid biosynthesis in adult periodical cicadas, Magicicada septendecim. Comparative Biochemistry and Physiology Part A: Molecular \& Integrative Physiology, 122(3), 355-362. https://doi.org/10.1016/S10956433(99)00018-5

Hodges, J.D., \& Barras, S.J. (1974). Fatty-Acid Composition of Dendroctonus frontalis at Various Developmental Stages1. Annals of the Entomological Society of America, 67(1), 51-54 https://doi.org/10.1093/aesa/67.1.51

Horobin, A.J., Shakesheff, K.M., Woodrow, S., Robinson, C., \& Pritchard, D.I. (2003). Maggots and wound healing: an investigation of the effects of secretions from Lucilia sericata larvae upon interactions between human dermal fibroblasts and extracellular matrix components. British Journal of Dermatology, 148(5), 923-933. https:// doi.org/10.1046/i.13652133.2003.05314.x

Jacob, J., \& Hanssen, H.-P. (1979). The Chemical Composition of Cuticular Lipids from Dragonflies (Odonata). Verlag der Zeitschrift für Naturforschung, 34(7-8), 498-502. https://doi.org/10.1515/znc-1979-7$\underline{802}$

Janda, V. (1975). Synthesis and utilization of tissue proteins and lipids during the larval-pupal transformation of Galleria mellonella. Acta Entomologica Bohemoslovaca, 72, 227-231.

Jurenka, R.A., Stanley-Samuelson, D.W., Loher, W., \& Blomquist, G.J. (1988). De novo biosynthesis of arachidonic acid and 5,11,14eicosatrienoic acid in the cricket Teleogryllus commodus. Biochimica et Biophysica Acta (BBA) - Lipids and Lipid Metabolism 963(1), 21-27. https://doi.org/10.1016/0005-2760(88)90333-5

Kalyoncu, L., \& Ozge, S. (2014). Fatty Acid Composition of Different Developmental Stages of Plodia Interpunctella (Hubner) (Lepidoptera:Pyralidae). Selcuk University Journal of Science, 38, 10-18.

Keeley, L.L., Park, J.H., Lu, K.H., \& Bradfield, J.Y. (1996). Neurohormone signal transduction for dual regulation of metabolism and gene expression in insects: Hypertrehalosemic hormone as a model. 33(3-4), 283-301. https://doi.org/10.1002/(SICI)1520-6327(1996)33:3/4

Lunas, B.M., de Paula, M.C., Michelutti, K.B., Lima-Junior, S.E., AntonialliJunior, W.F., \& Cardoso, C.A.L. (2019). Hydrocarbon and Fatty Acid Composition from Blowfly Eggs Represents a Potential Complementary Taxonomic Tool of Forensic Importance. Journal of Forensic Sciences, 64(6), 1720-1725. https://doi.org/10.1111/1556-4029.14119

Madariaga, M.A., Mata, F., Municio, A.M., \& Ribera, A. (1974). Changes in the fatty acid patterns of glycerolipids of Dacus oleae during metamorphosis and development. Insect Biochemistry, 4(2), 151-160. https://doi.org/10.1016/0020-1790(74)90003-1

Nor Aliza, A.R., Bedick, J.C., Rana, R.L., Tunaz, H., Hoback, W.W., \& Stanley, D.W. (2001). Arachidonic and eicosapentaenoic acids in tissues of the firefly, Photinus pyralis (Insecta: Coleoptera). Comparative 
Biochemistry and Physiology Part A: Molecular \& Integrative Physiology, 128(2), 251-257. https:// doi.org/10.1016/S1095-6433(00)00300-7

Nurullahoglu, Z.Ü. (2003). Fatty Acid Composition of Achroia grisella (Lepidoptera:Pyralidae) Larvae and Pupae. Selcuk University Journal of Science, 21, 75-78.

Ogg, C.L., \& Stanley-Samuelson, D.W. (1992). Phospholipid and triacylglycerol fatty acid compositions of the major life stages and selected tissues of the tobacco hornworm Manduca sexta. Comparative Biochemistry and Physiology Part B: Comparative Biochemistry, 101(3), 345351. https:// doi.org/10.1016/0305-0491(92)90011-F

Pagani, R., Suarez, A., \& Municio, A.M. (1980). Fatty acid patterns of the major lipid classes during development of Ceratitis capitata. Comparative Biochemistry and Physiology Part B: Comparative Biochemistry, 67(4), 511-518. https:// doi.org/10.1016/0305-0491(80)90408-3

Paul, A., Frederich, M., Megido, R.C., Alabi, T., Malik, P., Uyttenbroeck, R., Danthine, S. (2017). Insect fatty acids: A comparison of lipids from three Orthopterans and Tenebrio molitor L. larvae. Journal of Asia-Pacific Entomology, 20(2), 337-340. https://doi.org/10.1016/j.aspen.2017.02.001

Seven, S.E. (2004). Total lipid, total fatty acid and fatty acid composition of Plodia interpunctella(Lepidoptera:Pyralidae) larvae and pupae. (Master Master Thesis), (154034) r Retrieved https://tez.yok.gov.tr/UlusalTezMerkezi/tezSorguSonucYeni.jsp

Stanley-Samuelson, D.W., Jurenka, R.A., Cripps, C., Blomquist, G.J., \& de Renobales, M. (1988). Fatty acids in insects: Composition, metabolism, and biological significance. Archives of Insect Biochemistry and Physiology, 9(1), 1-33. https://doi.org/10.1002/arch.940090102

Stanley, D.W., \& Miller, J.S. (1998). Eicosanoids in animal reproduction what can we learn from invertebrates? In A. F. Rowley, H. Kühn, \& T. Schewe (Eds.), Eicosanoids and Related Compounds in Plants and Animals (pp. 183-196): Princeton University Press.

Sushchik, N.N., Yurchenko, Y.A., Gladyshev, M.I., Belevich, O.E., Kalachova, G.S., \& Kolmakova, A.A. (2013). Comparison of fatty acid contents and composition in major lipid classes of larvae and adults of mosquitoes (Diptera: Culicidae) from a steppe region. Insect Science, 20(5), 585-600. https:// doi.org/10.1111/j.1744-7917.2012.01582.x

Taşkın, D., \& Aksoylar, M. (2010). Fatty acid composition of larvae and pupae of Tenebrio molitor L. (Coleoptera: Tenebrionidae). Mehmet Akif Ersoy University, Journal of the Institute of Science, 1(2), 66-72.

Thompson, S.N. (1973). A review and comparative characterization of the fatty acid compositions of seven insect orders. Comparative Biochemistry and Physiology Part B: Comparative Biochemistry, 45(2), 467-482. https://doi.org/10.1016/0305-0491(73)90078-3

Wakayama, E.J., Dillwith, J.E., \& Blomquist, G.J. (1980). In vitro biosynthesis of prostaglandins in the reproductive tissues of the male house fly Musca domestica (L.). American Zoologist Abstract, 1010.

Zhang, Z., Wang, S., Diao, Y., Zhang, J., \& Lv, D. (2010). Fatty acid extracts from Lucilia sericata larvae promote murine cutaneous wound healing by angiogenic activity. Lipids in Health and Disease, 9(1), 24. https://doi.org/10.1186/1476-511X-9-24 